\title{
Editorial
}

\section{Between the Constitutional Document and the Constitutional Settlement}

Ten years ago, as the European Constitutional Treaty was made ready for signature, this journal was made ready for launching. Both events would take place at the end of October 2004. Our first issue was, of course, devoted to the Treaty. It broke down the document's substance into 24 key topics, each dealt with in turn by the members of the editorial and the advisory boards. From that first issue, the course of this journal would become inspired less by the document, however, than by the events concerning the constitutional settlement as it evolved for the Union.

The second issue was occasioned by the event of the Treaty's signing in Rome, on 29 October 2004. The reason was, paradoxically, that this coincided, both in time and in place, with the climax of the clash between the European Parliament and the European Council over the candidacy of Rocco Buttiglione as Commissioner for Justice and Rights. We noted that, auspiciously, these events could pour their political life into the constitutional document, itself somewhat vacuous and pretentious both as to its name and as to its form. Most of the contributions to that second issue then dealt with the domestic political roots of the Commission's authority, next to its roots in the EU appointment procedure.

Issue number 3 followed upon the formal Constitution's demise at the hand of French and Dutch referendums in the spring of 2005. It acknowledged the shock and reflected not only on the referendums themselves, but also on the effects of the events on the ways of European scholarship and teaching. Obviously, the loss of the document was not the end of our subject, nor even of the field of the constitutional law of the European Union. Constitutional law is not the field of law concerning the formal Constitution only. It is the law springing from and concerning the wider constitutional settlement, the political constitution or the constitution with a 'small c'. This constitution will normally include the formal Constitution or Basic Law. But constitutional law is not dependent on the latter's existence; otherwise there would be no constitutional law in the UK, Israel and other fully fledged constitutional entities without a formal Constitution. 
The EU's constitutional settlement depends not on the existence of a formal Constitution, but on the Union's real political authority, insofar as this is autonomous from the member states and their societies. While this autonomy may be quite limited, it is nevertheless undeniable. And it is to this constitutional settlement that EU constitutional law contributes.

Constitutional law thus depends, for its acknowledgment and for its development, on a wider-than-legal reality. This Constitutional Law Review was inspired by the Constitutional Treaty, all right, but could go ahead without it. The Union's constitutional law, both as a category and as a live and evolving reality, was acknowledged by the same Treaty, but had originated before it and could go ahead developing without it. And it would. Just think of the developments following elections.

In our second issue, on the Barroso drama, (better called the 'Buttiglione drama'), we noticed that the events played out so perfectly, with a lot of luck for the European Parliament, that the Parliament would find it a hard act for itself to follow. Now in the summer of 2014, just ten years later, the Parliament managed just that, and it even clearly managed to better itself. True, the election of Juncker to chair of the European Commission once more involved a lot of luck and circumstance, as had the veto of Buttiglione. But this time the event was a clear objective of the Parliament's strategy. And this time, the rule probably resulting from the clash, i.e. that the presidency of the Commission will be determined by the EP elections between opposing 'Spitzenkandidaten', is a rule much more powerful than the one coming out of the Buttiglione episode, i.e. that the EP can vote down individual Commission candidates in the appointment procedure.

For the existence of the rule, the causal relationship between the election and the appointment, to be plausible, it will need to be confirmed by the facts in the next round, preferably in a situation of conflict. Several other elements would also strengthen the argument about the existence of the rule. First: an anticipatory restructuring of the electoral process from the early stages on, with a greater presence of member state political leaders in the choice of 'Spitzenkandidaten'. We expect this to happen. Second: an open acknowledgment by the political leaders of the automaticity of the process - something still denied by a number of them before and during the 2014 nomination process, including Merkel, Rutte and, obviously, Cameron. Third: observance of the rule itself. It may be noted that observance of the rule is facilitated by a willingness of the European Council to take the nominating decision by a qualified majority vote - as evidenced by its recently outvoting Cameron.

It would be quite a setback for the Parliament if it would let this one slip away. If it does not, the established interpretation of the treaty provision (Art. 17(7) $\mathrm{TEU})$ prescribing the European Council to 'tak[e] into account the elections to 
the European Parliament' will now be that the presidency of the Commission will be determined by the EP elections between opposing 'Spitzenkandidaten'. The exact formula of this rule will depend on future events. It may very well turn out to be that the European Council nominates the winning 'Spitzenkandidat', as was the case in 2014, but this is not the only possible outcome. Depending on internal European Parliament dynamics, it could also be a less strict rule that the choice of Commission president should reasonably reflect the substantive outcome of the parliamentary vote. Or develop towards an entitlement of the 'Spitzenkandidat' of the biggest group to lead the consultations on the choice of a new Commission president (the mandate was this time given to the European Council president), both with the members of the European Council and with the political groups in the European Parliament. The latter interpretation would introduce an element of procedural automaticity, but no automaticity as to result.

Once the new rule is firmly part of the EU's constitution (small c), or constitutional settlement, as a key new rule enhancing the political authority of the system as a whole, it will have upgraded the Union's political constitution. One could in fact say that it will have brought a major shift from the intergovernmental to the political. At the same time the good old notional couple of intergovernmental v. supranational is being pushed further past its shelf date.

A set of further novelties and understandings has appeared from these elections. The most striking novelty is no doubt the way in which Italian prime minister Matteo Renzi, who came to power in Italy in February 2014 through a palace coup in his party, obtained a full democratic home legitimacy as prime minister through his local $42 \%$ score in these European elections. Far from being only 'second order elections', this ballot thus figured locally as a convincing 'first order one'.

Renzi proceeded to cash in on his victory at the European plane as well, by profiling himself immediately as the European Council member with the clearest, the most surprising and the freshest home power base. And a social democrat at that, quite against the tides. In this way European elections play off into results for different authorities, both at the European and the member state levels. Come to think about it, it is the same with national elections. These not only play off at the member state level, but also at the European one. After all, it is the national elections that normally provide both the membership of the European Council and its democratic underpinning. You might say that the parliamentary elections in most member states are, importantly, about whether the candidate prime minister from the right or from the left will be sent to the European Council.

Such electoral cross-overs appearing between the member states and the EU polity seem to have so far largely escaped the attention of constitutional legal scholarship, while they unmistakably enliven the EU's constitution both as to its 
structure and as to its bearing capacity. They are outside of the field of constitutional law in a strict sense. From the legal point of view, it is remarkable to what extent both the existence and the development of constitutional law in this EU polity have come to depend in part on such non-legal events and realities.

Some of the legal relevance of these developments will ultimately appear in law. The new rules may find their way to legal or paralegal documents, such as inter-institutional agreements, rules of procedure and even Treaty provisions. But many of the new elements of the relationships and bearings of the constitution, such as the electoral crossover just mentioned and the local political roots of the Commissioners' appointments (as in the Buttiglione drama), will be harder to keep track of in the EU's constitutional law. As part of the developing constitutional settlement, they are nevertheless clearly among the law's sources.

Inspired by the recent events, we now put to the attention of our readers the following question: there is an undeniable growth, both in width and in depth, of the EU's constitutional settlement, which in part escapes from the constitutional documents. How to account for this growth in terms of EU constitutional law?

A first part of an answer can be suggested in general and negative terms. It is this: concerning structure and foundations of the EU constitution, legal provisions and judgments cannot be counted on for the last word, be they provisions of EU law or of member state law. In this sense, the EU constitution is no different from national constitutions.

Between the document and the settlement there will be fertile ground to till for this journal in its coming decades. The same is true for the areas of national constitutional law in Europe and comparative constitutional law, which form an equally central part of the scope of this review.

WTE/TWB/JHR 